\title{
Exploring Discipline and Resistance in To Kill a Mockingbird from Perspective of Foucault's Theory of Power
}

\author{
Chen Sun ${ }^{1, \dagger}$, Dan Zhou ${ }^{2, *, \dagger}$ \\ ${ }^{1}$ School of Foreign Languages and Literature, Tianjin University, Tianjin, China \\ ${ }^{2}$ School of Foreign Languages, Central South University, Changsha, China \\ *Corresponding author.Email:201111012@csu.edu.cn \\ These authors contributed equally
}

\begin{abstract}
Modern society is a kind of disciplined society where individuals are intertwined in a network of power, being the object controlled by power and the role of wielding power. Harper Lee's novel To Kill a Mockingbird demonstrates that various disciplines control everyone. Townspeople with different gender, race and class identity have unconsciously accepted discipline or evidently suffered oppression from the discourse of patriarchy, racial discrimination, and rationality. Under different disciplines of power, some people are submissive without observing subtle forms of power, while others are dissatisfied with the status quo and rising against oppression. Combined with Foucault's theory of power, this paper explores the oppression that resulted from unequal power relations and resistance against the power of discourse. The study finds that women and children are the victims of patriarchal ideology; black folks lose their voice, dignity and civil rights under the constraints of racial hierarchy; and those who violate social norms would be regarded as freaks and expelled from the mainstream by rationality discourse. Eventually, the paper reveals diversified modes of power operation in Maycomb and Harper Lee's humanistic reflections on equality and justice.
\end{abstract}

Keywords: To Kill a Mockingbird, Foucault, power, discipline, resistance

\section{INTRODUCTION}

To Kill a Mockingbird was written by American writer Harper Lee and published in 1960. After winning the Pulitzer Prize in 1961, the novel was adapted for the screen and translated into more than forty languages, copies spreading worldwide. It is such an inspiring novel full of profound insights that it has long enjoyed enormous popularity. This unique bestseller has received unequaled acclaim from everywhere. Chicago Tribune describes it as "a novel of strong contemporary national significance", and the significance, in Haggerty's words, lies in its exposing the theme of racial segregation, exploitation and social injustice [1]. The New York Times also comments that "Miss Lee's original characters are people to cherish in this winning first novel." Narrated from a child's perspective, the novel presents readers a panorama of the small town Maycomb in the American South, where there are the eccentric Radley Family, alienated Cunningham's, notorious Ewell's, industrious Blacks, enlightened Finch's together with other traditional southern families. The climax of the story is an unwarranted accusation of rape against black man Tom Robinson, greatly reflecting the confrontation between social justice and racial inequality.

Previous studies on To Kill a Mockingbird have explored many aspects. Except for the frequently discussed metaphor that mockingbird as a symbol of innocence and Atticus Finch's image as a paragon of virtue, most topics revolved around educational and racial issues. Marian Spires analyzed the reason for To Kill a Mockingbird's classic privilege toward the education for 10th grade, constructed a unit exploring Harper Lee's gaps and silence, and investigated how Lee constructed different groups within her text to observe who held and exercised power [2]. Gregory Jay, from the following three parts that popularity and pedagogy, mockingbird on screen and in the classroom, and historicizing Lee: racism and rights at mid-century 
queer identifications, argued how the novel had been taught in school by analysis of "sexual otherness" and suggested how to reconsider this novel's continuous influence [3]. Michael Macaluso combined frameworks of new racism and critical literacy pedagogy to provide ideas and strategies for critically engaging, teaching, and reading with To Kill a Mockingbird [4]. Rezazade, Zohdi and Faghfori argued W.E.B. Du Bois' "double consciousness" was displayed in the characters in To Kill a Mockingbird. Their paper showed the theory of "veil" and "double consciousness" and then combined the theory with text, concluding that African Americans lived a dual life behind the veil of segregation [5]. Rezazade and Zohdi also applied Du Bois' thoughts regarding prejudice, discrimination, and racial injustice to investigate the power of being color-blind in the case of racism. They deemed that Atticus and three children were just individuals who evaluated people based on humanity and morality and treated Blacks as human beings regardless of skin color [6]. Dean Shackelford noticed some discrepancies between the film and novel versions that the racial dimensions of the novel had been overemphasized in the film, betraying the novel's full feminist implication. Hence, the passage revealed the importance of female voice and gender issues in the novel [7]. Furthermore, Iris Halpern examined the formation of contemporary epistemologies of gender by surveying the legal and cultural environment before and during desegregation in the South and then explored how constructs of femaleness and sexuality facilitated racial subordination and deciphered the legal system's function [8]. Rebecca H. Best explored Maycomb through the framework of the Panopticon and the Other that Michel Foucault set forth in Discipline and Punish [9]. She claimed that town dwellers lived within and were separated by strict social boundaries, and social position mandated proper behavior, which continuously reinforced stratification in society. Therefrom, Jem and Scout reached some sense of self-identity through their encounters with the Other.

To date, the results of previous studies have explicitly revealed the grave theme of anti-racism and the educational theme of children's awakening to social values. Little research, however, has delved into the subsequent repercussion incurred by characters' heterogeneous social identity and status. Those representative characters form an intertwined social network with multiple pairs of binary opposites, including children and adults, women and men, blacks and whites, irrational and rational, good and evil. The distinction between identities will inevitably entail an unbalanced distribution of power, which results in a ubiquitous superior-subordinate relationship. In other words, social injustice, prejudice and oppression are not confined to a conspicuous form of racism but fill every nook and cranny as long as there exist asymmetric social attributes in any interpersonal relationship. From the lens of Foucault's theory of power, the current study combines with detailed textual evidence to intensively examine the operational system of power in the cases of three antagonistic relationships. In other words, how does a superior group explicitly and implicitly expel its subordinate counterpart to a status of "the other" through the discourse of patriarchy, racial discrimination and rationality? Conversely, how does the underprivileged unwittingly accept the rule of power mechanism or spontaneously resist being outsiders of the mainstream society? This paper casts light on the imperceptible and pervasive power and discipline, hoping to deepen insight into manifold social injustice in a special historical era undergoing the Great Depression and enlighten readers to reflect on the contemporary status quo.

\section{THE OPPRESSION FROM THE DISCIPLINE OF POWER}

\subsection{The Power of Patriarchy Discourse: Oppression toward Women and Children}

The story of To Kill a Mockingbird takes place in an American South town named Maycomb during the Great Depression of the 1930s. Considering the social and historical context, it is a male-dominant society where male adults wield absolute authority in social and family circumstances. Accordingly, their roles as master of a house, children's father or wife's husband render their counterparts subordinate. As Emily Grierson is not the only miserable victim of patriarchy shown in literature, imperious patriarchy and submissive female voice are also depicted in To Kill a Mockingbird. The system of patriarchy manipulates its subordinate puppets by using multiple tangible devices and invisible forms.

Undisputed power is tacitly granted to men so that they naturally objectify women and juniors as part of personal possessions and further interfere in women's and children's lifestyle. This age-old social custom originates long before, and the early vestige can be found in Simon Finch's homestead, ancestral Finch's Landing, the layout of which to a great extent ensures the control of power within a certain range. Among the six bedrooms upstairs, four bedrooms are shared by eight female children while a single bedroom is occupied by Simon's sole son Welcome Finch and the remaining one is prepared in advance for visitors and relatives. In a sense, for the manor owner, nothing is more important than his legitimate heir and a decent impression left in others' minds, while as for his eight daughters, he gathers and supervises them like captive livestock, leaving no space for privacy. As the novel describes, there is only one staircase heading to the daughters' rooms, which is "in the ground-floor bedroom of their parents, so Simon always knew the 
hours of his daughters' nocturnal comings and goings" (p.106)[10]. Simon applies the Panopticon pattern where prisoners' movement would always be entirely exposed to the guards [11], infringing on their freedom of action.

Such surveillance inevitably evolves into full imprisonment with the device of physical torture, and sometimes an elder brother serves as a sort of surrogate father. Boo, Dill and Mayella have all been placed under house arrest. In the case of Boo Radley, after being considered crazy, he is "not seen again for fifteen years" (p.13)[10], and his brother Nathan Radley fills up the hole in the tree to prevent Boo from exchanging gifts with the children (p.83)[10]. No one knows what happened exactly in the silent and closed Radley house, where individual voice is shrouded and chocked by overwhelming patriarchal power. Moreover, Dill's stepfather and Bob Ewell represent the type of lynch mobs. The former "binds Dill in chains and leaves him to die in the basement" simply out of a feeling of detestation (p.186)[10], while the latter not only imposes all the burden of household chores on Mayella but also commits the crime of incest by treating his daughter as a sex slave to vent sexual desires. Irritated by Mayella's intimacy with Tom, Bob Ewell punches her in the face. These common cases of domestic abuse indicate that women and children are completely reduced to a disposable item in the family, and the master of the house, especially man as a father, never hesitate to exert perverse brutality to blatantly declare their dominion over female's sexuality and over individual's life and death.

Establishing a social construct is an invisible way of infiltrating disciplinary mechanisms into the patriarchal society. Specifically, religious discourse and gender stereotypes function as behavioral and ideological constraints of power to make women succumb to preconceived notions set by men. When women consciously take the gender norms of patriarchy as their code of conduct, they lose self-consciousness and successfully fulfill the goal of discipline set by patriarchal society. Clergymen are the main representatives who exert the power of discourse to preach "educational" sermons that portray women as a sin and juxtapose women with other evils like alcoholics and gamblers. On many occasions, Scout is "confronted with the Impurity of Women doctrine" (p.162)[10] and instructions that "girls should spend enough time inside the house reading the Bible" (p.59)[10]. These restrictions and fetters belittle women to a disgraceful image and confine their social activities to a narrow domestic setting. Subsequently, patriarchy creates an ideal concept of an elegant Southern lady for women to obey the rule. For instance, Scout is more than once admonished by Mrs. Dubose and Aunt Alexandra to dress like a girl who should be in a dress and camisole and behave politely. Shackelford points out that Lee criticized Southern women and their narrow-mindedness concerning gender roles [7], yet they are also victims of patriarchy and always living under the male gaze. Diverting women's attention away from their society's core business and legal affairs, men make Southern ladies concentrate on superficial appearance and gossip about mundane, trivial matters all day. Consequently, women and children are expelled from men's fields and confined to a minor matter, being the others.

\subsection{The Power of Racial Discrimination Discourse: Prejudice toward Blacks}

Modern disciplinary society is a big prison consisting of hospitals, mental hospitals, factories, schools, barracks, asylums, nursing homes, institutions, and other kinds of "prisons" that form a so-called "prison archipelago". Everyone is in this "prison archipelago" without being aware of it, and everyone is under close surveillance of the "eyes of power" without any escape.

This section moves on to the discourse of racial discrimination, focusing on the prejudice toward blacks in the novel. The origin of biased discourse in the United States can be traced back to the eighteenth century as a justification for slavery. The society at that time generated an irrational linkage between visible biological features and intangible moral nature by derogating oppressed Africans as inferior to maintain a structural hierarchy for exploitation and domination. Though slavery has demised, racial ideology as a discourse of power has never perished since "we continue to create and re-create it in our social life" [12]. In terms of Foucault's theory, no matter what methods are used, the ruling class's solely purpose is to make the ruled class tamed by regulating their bodies. The process regulating a body is like the process of domesticating a beast, and the body of the ruled becomes a plaything of power [13]. Whites, as the ruling class toward blacks, manipulate a discourse to make blacks comply with established rules. Some key words of race discourse are reflections of social relations of power and racial ideology, which create and maintain a new social order characterized by "orthodox white hegemony" through influencing or manipulating people's thoughts as well as value orientation. Ingrained thought of racial inequality or discrimination always reminds people of some gloomy cases that happen to black folks portrayed in the novel. For instance, "negro" in the novel is a widely-used appellation for blacks, full of disdain and disrespect toward blacks.

In To Kill a Mockingbird, Tom Robinson is accused of raping a white girl, Mayella Ewell. In spite of Tom's innocence, he is sentenced to jail and later Tom is shot and killed brutally by a correctional officer while trying to escape. The text writes that "to this court, in the cynical confidence that their testimony would not be 
doubted, confident that you gentlemen would go along with them on the assumption - the evil assumptionthat all Negroes lie, that all Negroes are immoral beings, that all Negro men are not to be trusted around our women, an assumption one associate with minds of their caliber" (p.273)[10]. Fanon argues that since civilized white men retain an irrational longing for unusual eras of sexual license, of orgiastic scenes, the white men behave "as if Negro really had them" by projecting their desires onto the Negro [14]. The vast majority is controlled by the racial discourse and that is why Tom is labeled as a rapist regardless of his innocence and what he has certified in court. Generally, blacks are regarded as collective violators of traditional morality, who may have characteristics like laziness and immorality [15]. This set of stereotypes severely undermines the credibility of blacks' voices. Lamont's sociological investigation reveals a reality that many of white workers associate themselves with responsibility and diligence but think of blacks' identity as the opposite side. The whites use ethical and moral standards to place themselves above blacks. Obviously, anonymous townspeople in Maycomb have widely accepted this mindset, slandering a black man without any solid evidence. In the novel, however, Lee moves beyond typical white's perspective to disclose another truth that Ewell's family are hardly getting rid of welfare and dependency, whereas Tom and some blacks in the church show good merits, like industry, integrity, kindness and neatness. Therefore, the loss of Tom's court case indicates not only a social value with racial prejudice, but also a fossilized power structure where all blacks are at the bottom and whites at the top [16].

The power structure is deeply embedded in socioeconomic status, judicial system and social life. In To Kill a Mockingbird, in the eyes of white people, blacks are doomed to be servants for them. There is a scene that Scout holds up her hands, and a network of tiny lines crisscross her palms, brown with dirt and dried blood. Jem says, "You have ruined them. Why don't you get a colored man?" (p.98)[10]. Regarding tough work, Jem, a child, would even assign arduous work to people of color, especially toward blacks. In general, blacks like the garbage collector Zeebo and domestic servant Calpurnia are engaged in manual labor with low income and low social status, yet whites take up intellectual professions of lawyer, dentist, teacher, and judge with authority to make all sorts of decisions.

This pattern of socioeconomic status further causes black's "aphasia" within the judicial system. According to Reverend Sykes's experience, he "ain't ever seen any jury decide in favor of a colored man over a white man" (p.279)[10], indicating that there are few precedents for blacks to win a lawsuit against whites. Since the decisive jury is composed of white people, Atticus has accurately predicted in the beginning that "the jury couldn't possibly be expected to take Tom Robinson's word against the Ewells" (p.117)[10], and it is confirmed in the end that "the white man always wins because there's something in our world that makes men lose their heads - they couldn't be fair if they tried" (p.295)[10]. That shows the power of biased racial discourse. White men exert power in the legal field to guarantee white supremacy, especially in the American South, proved by historical evidence Jim Crow Laws.

Moreover, under the supervision of legal power, blacks are drowning in unequal segregation. The text writes, "It was an ancient paint-peeled frame building, the only church in Maycomb with a steeple and bell, called First Purchase because it was paid for from the first earnings of freed slaves. Negroes worshiped in it on Sundays, and white men gambled in it on weekdays" (p.157)[10]. Blacks and whites should own their church separately, but faced with whites' arbitrary invasion of their sacred territory, and black folks have no equal legal status to drive gamblers away. The black community totally loses a powerful voice to defend themselves. Thus, the separation does not put blacks and whites on an equal footing but forms racial stratification where blacks are typically at a disadvantage.

The separation is in accord with cells in the Panopticon, which Foucault extends into daily life, and people are under "the vigilance of intersecting gazes". Members of one group who reach out to members of another group will be pushed out of the system altogether or dealt with harshly within the system [9]. Atticus Finch, a white lawyer who speaks in defense of Tom Robinson, is censured and ridiculed by other white people in Maycomb. Finch's children are surprised one morning to see a cartoon in the Montgomery Advertiser above the caption, "Maycomb's Finch", which depicts that "Atticus barefooted and in short pants, chained to a desk: he was diligently writing on a slate while some frivolous-looking girls yelled, 'Yoo-hoo!' at him" (p.155)[10]. Even though he is white, Atticus still suffers abuse and calumniation from other whites for his assistance toward a black. Similarly, it is also inappropriate to cross the language border. Calpurnia talks colored-folks' talk at church and with her neighbors, avoiding being ostracized by the black community. Otherwise, members of the community would think Calpurnia is "putting on airs to beat Moses" (p.167)[10].

\subsection{The Power of Rationality Discourse: Marginalization of Irrationality}

Foucault argues that madness is a form of suffering and, in a sense, the last form before death, so those bearing it are reduced to be an object of sympathy [17]. Boo Radley, who is put under house arrest by his father, is regarded as a madman, being subjected to isolation and misconstruction by the whole residents of Maycomb. However, as Foucault argues, Boo Radley 
also plays the role of being sympathized. "Miss Stephanie Crawford said some of the town council told Mr. Radley that if he did not take Boo back, Boo would die of mold from the damp. Besides, Boo could not live forever on the bounty of the county" (p.14)[10]. Confinement divulges the shame of irrationality by concealing the shame, but openly draws attention to and focuses on insanity [17]. Even though Boo is not insane, in fact under house arrest, everyone is convinced of his insanity because of his state of being confined. As the conversation between Scout and Miss Maudie shows, "No, child, that is a sad house. I remember Arthur Radley when he was a boy. He always spoke nicely to me, no matter what folks said he did. Spoke as nicely as he knew how." "You reckon he is crazy?" Miss Maudie shook her head. "If he is not, he should be by now. The things that happen to people we never really know" (p.61)[10].

The confinement center punishes all offenders, vagrants and idlers who are not mentally ill and attempts to impose total mental and physical restraint on them in forced labor [17]. The confinement of Boo Radley magnifies his irrationality, bringing him into the public vision, which considers his madness. And the stereotype toward Mr. Radley has deeply rooted among people that inside the house living a malevolent phantom. It is widely rumored that "he went out at night when the moon was down and peeped in windows. When people's azaleas froze in a cold snap, it was because he had breathed on them" (p.10)[10].

Deprived of discourse, Raymond is regarded as irrational for violating social rules because of his marital relationship with black women. The rationality marginalizes and silences irrationality to establish the dominant status of rationality. Thus, to escape judgment from rationality, Raymond says, "I try to give them a reason, you see. It helps folks if they can latch onto a reason. When I come to town, which is seldom, folks can say Dolphus Raymond's in the clutches of whiskey if I weave a little and drink out of this sack" (p.268)[10]. As the "other", Raymond generally refers to the object exclusion from the traditional rational subject, being degenerated to marginal person.

\section{THE RESISTANCE AGAINST THE DISCIPLINE OF POWER}

Foucault points out that there is no "power relationship without resistance, which is more real and effective because they are just formed at the point where the power relationship is practiced." Foucault's resistance does not exist before the power against it, nor does it arise from a field outside the power relationship, but it also depends on the place where the power relationship is practiced.

\subsection{The Resistance against the Patriarchal System}

Women are all ambiguous subjects in the midst of the suppression and monitoring of regulatory power. In the disciplinary space, women display their bodies, expose their privacy, and place themselves in the view of male viewers, accepting the gaze of male, and thus satisfying men's desire for voyeurism. Women are the other, with no real voice to speak of the self and no self to speak of. The discourse of male subjects annihilates the voice of women. Scout Finch, a six-old little girl, represents the independent spirit of the new woman in America. Under the discourse of patriarchy, she not only does not approve of rules imposed on women but dares to resist creeds and standards based on the power of patriarchy discourse. Scout says that, "I reluctantly played assorted ladies who entered the script" (p.52)[10]. "But I kept aloof from their foolhardier schemes for a while and on pain of being called a girl" (p.55)[10]. It is clear for Scout to know that she is different from the ideal body of woman and femininity. Terms like "gender norms" and "constructed female" do not exist in the mind of Scout, and she even does not know what disciplined power and resistance are. However, her choice of clothes and unconscious behavior precisely certify her resistance against patriarchy discourse. Likewise, Miss Maudie also represents the spirit of the new woman in America. The description for Miss Maudie reads that "she was a widow, a chameleon lady who worked in her flower beds in an old straw hat and men's coveralls, but after her five o'clock bath, she would appear on the porch and reign over the street in magisterial beauty" (p.56)[10]. Her self-consciousness and position in this world are determined by socialized gender norms, not her internal thinking about what kind of woman she is. However, Miss Maudie tries to keep away from normal gender construction to resist the interpretation of femininity.

Being under house arrest by his father, as the same as Boo Radley, Dill chooses to flee away and free himself to resist the power of his stepfather. Having been bound in chains and left to die in the basement by his new father who dislikes him, Dill works himself free by pulling the chains from the wall and secretly keeps alive on raw field peas offered by a passing farmer who hears his cries for help (p.187)[10]. Where there is power, there is resistance. There is an inherent relationship between resistance and power. Stepfather's confinement to Dill demonstrates the power of patriarchy discourse, whereas Dill's escape from the basement shows his determination to resist his father without any hesitation.

Lefebvre argues that all "subjects" in a space in which they must either recognize themselves or lose themselves, a space which they may both enjoy and modify [18]. Mayella Ewell, who is imprisoned by the 
space of paternal and white supremacy society and as an outsider segregated both by white people and blacks, never enjoys kinship and friendship. "White people would not have anything to do with her because she lived among pigs; Negroes would not have anything to do with her because she was white" (p.256)[10]. She represents some southern women in the 1930s, born in the lower class, receiving orders from their paternal class, and having no choice for their fate. Oppressed by the paternal power to a large extent, Mayella cannot stand repression from his father and white group, so that she is suppressed to the extreme and rises to resist, violating the rules for a white woman to keep away from blacks.

\subsection{The Resistance against Racial Discrimination Discourse}

In addition to the resistance against patriarchy, antiracism is another distinctive theme of the novel heatedly discussed. Halpern writes that the characters in Lee's novel are admirable only because they duel against the nation's malefic history of pervasive structural violence against African Americans [8]. Although the word "only" is relatively limited because analysis in the previous section has reflected characters' merits to shake off the shackles of patriarchy, Halpern does remind us of characters' great efforts in dispelling racial discourse. Rezazade and Zohdi invoke Ralph Waldo Emerson's notion "transparent eyeball" to appraise the colorblindness characteristic of Atticus and three children Dill, Scout and Jem, demonstrating that they are a group of people who make no classifications or distinctions based on race but humanity [6]. Casting aside such an absurd racial ideology is the first step to fight against racial discrimination, to ensure that they do not become conspirators of power oppression. More noteworthy are those positive characters' overt and covert attempts to subvert this discourse.

Atticus Finch as a lawyer, is the exact embodiment of justice in the novel, skin tone never being his yardstick of individuals' performance. Facing Alexander's intention to fire the black maid Calpurnia, Atticus firmly asserts that "Calpurnia's not leaving this house until she wants to. She's a faithful member of this family. If anything, she's been harder on them in some ways than a mother would have been... she's never let them get away with anything, she's never indulged them the way most colored nurses do. She tried to bring them up according to her lights, and Cal's lights are pretty good" (p.183)[10]. Calpurnia is able to manage affairs and make decisions at her own discretion and even enjoys the right to educate white employer's children in the light of her moral values and expectations. In other words, Calpurnia is not an abject negro servant only responsible for domestic chores, but an equal member of Finch's family. It is Atticus who shows great respect to
Calpurnia, recognizing her identity as a human being and approving of blacks' code of conduct. Atticus's actions that returning the deprived human rights to blacks and living harmoniously with Calpurnia are out of tune with the social and historical context of Maycomb, so this resistance has depicted a promising vision for the benighted South society.

Besides, Atticus's advocacy of Tom's innocence turns him on the opposite side of the mainstream. Regardless of reprimand, humiliation, and doomed failure, he takes Tom Robinson's case seriously with all his might because "it is something that goes to the essence of a man's conscience" (p.139)[10]. Obviously, there is little hope for winning the case, so Atticus's original intention is to expose the truth to the public and prove that Tom is innocent rather than guilty in morality and reality. Taking advantage of the interrogation and defense, Atticus repeatedly delivers some crucial messages to audiences in the court that "some Negroes lie, some Negroes are immoral, some Negro men are not to be trusted around women - black or white. But this is a truth that applies to the human race and to no particular race of men. Thomas Jefferson once said that all men are created equal" (p.273)[10]. The voice of Atticus is a flash of lightning and thunder trying to crack down on the prevailing narrow-minded racial prejudice in the South. He gives a lecture that people should eliminate general stereotypes and focus on facts, hoping to arouse their conscience. Atticus educates the next generation in the same way, telling his children "you never really understand a person until you consider things from his point of view" (p.39)[10]. Therefore, through his actions, Atticus not only challenges the deep-rooted racial discrimination discourse, but also promotes the dissemination of anti-racial ideas to establish a fair and just social order by means of edification.

Atticus is a significant and overt representative of resistance, and he does not fight alone. It should be noted that an underlying trend of the appeal for racial equality is surging among intellectuals in the South. After the Civil War and Reconstruction periods, a progressive civilization from American North gradually penetrated the South. For instance, Miss Caroline Fisher, who comes from Winston County, North Alabama, is a typical symbol of the northern civilization, which continuously rectifies old traditions of the South. With regard to human rights, "the Yankees and the distaff side of the Executive branch in Washington are fond of hurling at" Southerners (p.274)[10], leading to a change of intellectuals' racial ideology. Miss Maudie drops a hint to Jem that in Maycomb, more than one person is assisting Tom Robinson. "His colored friends for one thing, and people like us. People like Judge Taylor. People like Mr. Heck Tate. Did it ever strike you that Judge Taylor naming Atticus to defend that boy was no accident? That Judge Taylor might have had his reasons 
for naming him" (p.289)[10]. Judge Taylor assigns the court-appointed defense to Atticus Finch with great deliberation, or Tom Robinson's case would be simply given to any novice lawyer. Clearly recognizing the severe social reality, everyone initially has foreknowledge of the court's final decision, but still tries to overthrow the status quo. Jury's suspension, hesitation, and argument during making decisions is another form of Atticus's victory. Even if the most blatant resistance, in reality, is like the tragic ending of Tom escaping from prison, the upsurging resistance, as Miss Maudie ruminates, "it's just a baby-step, but it's a step" (p.289)[10].

\subsection{The Resistance against Rationality Discourse}

Unlike people in Maycomb, Atticus never associates himself with undesirable elements, ridiculing and isolating Boo Radley. Toward mischievous games of Dill, Jem and Scout, Atticus expresses his attitude that "what Mr. Radley did was his own business. If he wanted to come out, he would. If he wanted to stay inside his own house, he had the right to stay inside free from the attentions of inquisitive children, which was a mild term for the likes of us" (p.65)[10]. Atticus does not consider Boo Radley as a madman but teaches his children to respect Mrs. Boo, regarding Boo as a normal person. Atticus' behaviors shows his implied resistance against rationality.

On the surface, rationality is used to help the people get rid of irrationality, but in essence, people are framed as an object to be legitimized and disciplined by rationality, which is still on the same path of strengthening anti-rationality [19]. In order to respond to the question from Scout, Raymond says, "oh yes, you mean why do I pretend? Well, it is very simple. Some folks don't-like the way I live. Now I could say the hell with them. I do not care if they do not like it. I do say I do not care if they do not like it, right enough - but I do not say the hell with them" (p.268)[10]. Having a sexual relationship with a black woman means extraordinary shame and humiliation for white, while Raymond has to pretend an alcoholic being drunken every day to escape or even resist the judgment from white. Raymond, as the object disciplined by rationality, pretending an alcoholic is his way of anti-rationality. When capitalism promotes its hypocritical morality in the name of reason in secular life, people either put on the shackles of reason, or fervently pursue fame and fortune, or experience the primitive pleasure of living in the sharp hiss of desire [20]. It comes to a deduction that out of primitive pleasure, Raymond ignores skin tone and keeps intermarriage with a black woman to resist the discourse of rationality.

\section{CONCLUSION}

This paper applies Michael Foucault's theory of power discourse to reveal three kinds of power discourse at work in shaping people's lives in society and how people resist discipline under various power. There are three kinds of power in Maycomb, patriarchy, racial discrimination, and rationality discourse. It can be seen that, in this novel, everyone has been disciplined by various rules in society, so that, sometimes, they have suffered oppression or have to seclude themselves from reality. Under the power of patriarchy, women and children, like Scout Finch, Dill and Boo Radley, who are all victims of patriarchal society, cannot defend their rights. Disciplined by racial discrimination discourse, blacks, especially blacks in the American South, have suffered extremely inhuman treatment that infiltrates all aspects of life, like culture, institution and so on. As for rationality discourse, people like Raymond have been put on the shackles of reason, so that they have to pretend to be mad or hide their true self to escape the judgment of rationality. However, while consciousness is awakening, a group of people resort to resisting such rules imposed on them.

In terms of the future research for To Kill a Mockingbird, it is a good direction for researchers to study the situation of modern people disciplined by power because, as Foucault says, our modern society is disciplined. Inspired by methods of characters in this novel resisting the oppression from various power, future research should focus on modern people, studying how they raise consciousness and resist against the discipline. This paper merely argues the discipline and resistance in To Kill a Mockingbird based on the behaviors of characters without extending to the social reality.

Applying Foucault's theory to To Kill a Mockingbird, it comes to Harper Lee's morality that, as any society is a disciplinary mechanism that may bring about injustice and inequality under its power discourse, everyone should try best to improve the social system by appealing and upholding justice, and more importantly, to share the conviction that all humans are born equal.

\section{ACKNOWLEDGMENTS}

We thank Tianjin University Library and Central South University Library for providing adequate academic resources. We are indebted to Professor James Herron for recommending significant books on race and racial inequality studies in America. Thanks also go to Professor Jie Zhang and Professor Zhuqing Zeng, who gave us valuable suggestions. We thank Yuwei Yang for meticulously reviewing the first draft of this article, and we gratefully acknowledge the constructive comments of the editor and anonymous reviewers. 


\section{REFERENCES}

[1] M.I. Khokhar, G.M. Mashori, Marxist Analysis of To Kill a Mockingbird According to Peter Barry, Grassroots, Vol.52, No.2, 2018, pp.179-191. https://sujo-

old.usindh.edu.pk/index.php/Grassroots/article/vie w/4841

[2] M. Spires, Developing a Critical Literacy Approach with To Kill a Mockingbird, English in Australia, Vol.126, 1999, pp.53-59. https://www.researchgate.net/publication/2345936 80_Developing_a_Critical_Literacy_Approach_wit h_To_Kill_a_Mockingbird

[3] G. Jay, Queer Children and Representative Men: Harper Lee, Racial Liberalism, and the Dilemma of To Kill a Mockingbird, American Literary History, Vol.27, No.3, 2015, pp.487-522. DOI: https://doi.org/10.1093/alh/ajv023

[4] M. Macaluso, Teaching To Kill a Mockingbird Today: Coming to Terms With Race, Racism, and America's Novel, Journal of Adolescent \& Adult Literacy, Vol.61, No.32, 2017, pp.279-287. DOI: https://doi.org/10.1002/jaal.678

[5] F. Rezazade, E. Zohdi, S. Faghfori, Negro's "Double Consciousness" in To Kill a Mockingbird, Theory and Practice in Language Studies, Vol.6, No.12, 2016, pp.2292-2296. DOI: http://dx.doi.org/10.17507/tpls.0612.08

[6] F. Rezazade, E. Zohdi, The Power of Being ColorBlind in To Kill a Mockingbird, International Letters of Social and Humanistic Sciences, Vol. 71, 2016, pp.47-53. DOI: https://doi.org/10.18052/www.scipress.com/ILSHS .71 .47

[7] D. Shackelford, The Female Voice in To Kill a Mockingbird: Narrative Strategies in Film and Novel, The Mississippi Quarterly, Vol.50, No.1, 1996 , pp.101-113. https://www.jstor.org/stable/26475781

[8] I. Halpern, Rape, Incest, and Harper Lee's To Kill a Mockingbird: On Alabama's Legal Construction of Gender and Sexuality in the Context of Racial Subordination, Columbia Journal of Gender and Law, Vol.18, No.3, 2009, pp.743-806. DOI: https://doi.org/10.7916/cjgl.v18i3.2576

[9] R.H. Best, Panopticism and the Use of "the Other" in To Kill a Mockingbird, The Mississippi Quarterly, Vol.62, No.4, 2009, pp.541-552. https://www.jstor.org/stable/26477256

[10] H. Lee, To Kill a Mockingbird, GC Publishing, 1976.
[11] M. Foucault, Discipline and Punish: The Birth of the Prison, trans. Alan Sheridan, New York, Pantheon Books, 1977, pp.200-201.

[12] B.J. Fields, Slavery, Race and Ideology in the United States of America, New Left Review, pp.95-118.

https://newleftreview.org/issues/i181/articles/barba ra-jeanne-fields-slavery-race-and-ideology-in-theunited-states-of-america

[13] Y.F. Hu, Disciplinary Power and Disciplinary Society: New Exploration on Foucault's Power Theory, Zhejiang Social Sciences, No.1, 2013, pp.114-119+145+159.

DOI: 10.14167/j.zjss.2013.01.008.

[14] F. Fanon, Black Skin, White Masks, U.K., Pluto Press, 2008, p.127.

[15] M. Lamont, "Euphemized Racism: Moral qua Racial Boundaries" in The Dignity of Working Men, Harvard University Press, 2009, p.64.

[16] A. Smedley, B.D. Smedley, Race in North America: Origin and Evolution of a Worldview (4th ed.), Boulder, CO, Westview Press, 2012, p.153.

[17] M. Foucault, Discipline and Punish: The Birth of the Prison, trans. Liu Beicheng, Yang Yuanying, Beijing, SDX Joint Publishing Company, 2003, pp. $73+63+57$.

[18] H. Lefebvre, The Production of Space, trans. Donald Nicholson Smith, Oxford, Blackwell, 1991, p.35.

[19] Y. Liu, The Deep Path in Foucault's Critique of Reason and Its Enlightenments for Post-Theory, Theoretical Studies in Literature and Art, No.1, 2019, pp. $27-37$ https://d.wanfangdata.com.cn/periodical/wyllyj201 901003

[20] J.J. Tao, Introduction to Identity, Foreign Literature, No.2, 2004, pp.37-44. DOI: 10.16430/j.cnki.fl.2004.02.011. 